\title{
Pandemi, krisehåndtering og arbejdsliv
}

$\mathrm{D}$ a Mette Frederiksen lukkede ned for det danske samfund i midten af marts måned 2020 - som respons på den globale coronapandemi - var det en historisk uset grad af intervention på det danske arbejdsmarked, der medførte en næsten øjeblikkelig nedlukning for mange danske arbejdspladser både i det private og det offentlige. Det var på mange måder en usædvanlig beslutning, som fik store konsekvenser på stort set alle samfundsområder. Siden anden Verdenskrig, har der ikke været gennemført så pludselige og omfattende ændringer af arbejdsvilkår og arbejdets organisering med konsekvenser for de sociale relationer på arbejdspladser og for forholdene på arbejdsmarkedet mere generelt, som det skete under coronapandemien.

I starten steg arbejdsløsheden voldsomt, og man indførte en række hjælpepakker til både virksomheder og lønmodtagere, som blev hjemsendt, f.eks. den såkaldte lønkompensation som skulle holde hånden under de ansatte i særligt udsatte brancher. Denne tilgang var ikke unik for Danmark. Som Trine P. Larsen og Anna Ilsøe viser i deres bidrag til dette temanummer, blev der i alle de nordiske lande men på forskellig vis iværksat hjælpepakker og lempelser af regler. Dette skulle afbøde konsekvenserne af en politik, der i høj grad satte folkesundheden højere end de umiddelbare økonomiske konsekvenser heraf. Virksomhederne blev opfordret til i så vidt omfang som muligt at undgå at afskedige deres medarbejdere og i stedet for søge denne kompensation fra staten.

Men nedlukningen medførte også forandringer i arbejdsvilkårene for mange men- nesker. Ikke alene de ansatte i rejse, hotel- og restaurationsbranchen, men også i store dele af detailhandlen blev sendt hjem uden arbejdsopgaver til en hverdag, der ikke var ulig den arbejdsløse oplever med de udfordringer for hverdagslivets rutiner og identiteten det medfører. Offentligt ansatte i ikke-kritiske funktioner blev beordret hjem at arbejde, hvilket blandt andet medførte et skifte i arbejdsvilkårene, da man fra den ene dag skulle varetage arbejdet fra hjem der ikke var indrettet som arbejdspladser og måske samtidig passe og undervise sine egne børn. Den grænseløshed i arbejdet som hermed blev skabt og de muligheder for nye balancer mellem arbejde og fritid er et af omdrejningspunkterne i Steen Navrbjerg og Dana Minbaeva kronik i dette temanummer.

At medarbejderne ikke var fysisk til stede på arbejdspladsen havde også betydning for den måde hvorpå HR-medarbejdere og ledelse kunne forholde medarbejderne. Distanceledelse kræver, som Malene F. Andersen og Claus Elmholt peger på i deres bidrag, andre greb når medarbejdernes trivsel og produktivitet skal sikres. Lotte Holck og Iben S. Stjerne peger desuden i deres bidrag på, hvordan krisen tydeliggør mere fundamentale ambivalenser i personaleledelse; ambivalenser mellem hård HRM med snævert fokus på økonomi og blød HRM med fokus på medarbejder trivsel og udvikling.

I både den offentlige og private sektor fortsatte medarbejdere i kritiske funktioner (f.eks. ansatte i fødevarebutikker og sundhedspersonale) arbejdet med risiko for at blive smittet med Covid-19. Især i sundhedssektoren 
blev etablerede regler og normer; det være sig for arbejdstid, faggrænser og ansættelsesvilkår, med begrundelse i krisesituationen sat på pause. Pandemien blev dermed også et laboratorium for hyperfleksibilisering af arbejdet; mod et arbejde med maximal omstillingsparathed med flydende faggrænser og tidsgrænser.

Coronapandemien fik også betydning for de ledige; både de der allerede stod uden arbejde, da landet lukkede ned, men også de der blev afskediget som følge af nedlukningerne. For begge grupper gjaldt, at den aktive beskæftigelsesindsats blev midlertidigt suspenderet, hvilket betød, at ledige stadig modtog ydelser, men ikke var underlagt rådighedskrav, jobsøgningskrav, deltagelse i fysiske samtaler hos jobcentre og a-kasser og aktive beskæftigelsesindsatser. Sabina Pultz og Magnus P. Hansen peger i deres bidrag til temanummeret på, at der tilsyneladende pågik en forskydning i den måde de ledige forholdt sig til deres egen situation på. På trods af de lempeligere regler var der en tendens til at de ledige fik mere ejerskab over og motivation til deres jobsøgning, mens de der blev ramt af ledighed som en direkte følge af pandemien blev betragtet som mere værdigt trængende fordi deres ledighedssituation var uden for deres kontrol.

Coronapandemien repræsenterer en acceleration af nogle eksisterende udviklingstendenser, men også interessante brud med eksisterende udviklingsbaner. Pandemien er blevet beskrevet som en prisme og fremkaldervæske, der gør nogle udviklingstræk i arbejdslivet mere tydelige, og kan også give enestående muligheder for at studere sammenhænge og konsekvenser, som rækker ind i fremtidens arbejdsmiljø, arbejdsliv eller nye samspil mellem stat og arbejdsmarked.

Pandemien giver således særlige muligheder for at studere den øgede virtualisering af arbejdet som i lang tid har været diskuteret som en del af tendensen til grænseløshed i arbejdet, hvor faste grænser om tid og sted for arbejdet er under opløsning. Med pandemien og de teknologiske arrangementer der her bliver etableret, bliver særligt virtualiseringens betydning for sociale relationer, fællesskaber i arbejdet, trivslen og relationsarbejdet med klienter, elever, patienter tydelig. Det samme gælder hjemmearbejde, som er blevet normen for mange mennesker. Fleksibilitetens mange ansigter og de stadige forhandlinger af balancen mellem privat og arbejdsliv er således et af de træk i det moderne arbejde som pandemien eksponerede. Distanceledelse er en konsekvens af denne udvikling, og betydningen af ledelse og ledelsesrelationer blev således også et af de forhold, der tydeligt trådte frem under pandemien.

På makroplan tyder krisen også på en midlertidig suspension af den neoliberale økonomiske model; en tilbagevenden til en mere keynesiansk inspireret forståelse af krisehåndtering, hvor statslig intervention i økonomien med forskellige typer af hjælpepakker spiller en vigtig rolle, og hvor arbejdsløshed i højere grad anskues som et strukturelt fænomen. Denne form for ændringer giver unikke muligheder for at studere paradigmatiske forandringer på arbejdsmarkedet og deres konsekvenser på forskellige områder.

Alt i alt er der tale om meget forskelligartede problematikker, og dette temanummer kan selvfølgelig ikke hverken give en dækkende eller udtømmende indblik i de mange forskellig problematikker og felter inden for arbejdslivet som krisen berørte. Temanummeret skal først og fremmest ses som et kig ind i fremtidige tendenser i arbejdslivet; tendenser som er sat under lup. Vi præsenterer således en broget buket af artikler som handler om så forskellige tematikker som arbejdsløses selvansvar for egen ledighed, distanceledelse af trivsel, om kriseledelse i HR gruppen, og om hjælpepakkernes forskellige betydning for atypisk beskæftigede i de nordiske lande. 
Temanummeret rummer fire artikler samt en kronik. I den første artikel ' Arbejdsløs i en (corona) krisetid - et opgør med selvansvaret' viser Sabina Pultz og Magnus P. Hansen hvordan forståelsen af arbejdsløshed forandrede sig under coronakrisen. På baggrund af interviews og spørgeskemaundersøgelse til arbejdsløse under coronakrisens første fase i 2020 finder Pultz og Hansen, at personer som mistede arbejdet under pandemien i højere grad oplevede sig som uforskyldte i deres ledighed. Det markerede et brud med årtiers individualisering og selvbebrejdelse blandt arbejdsløse. Til trods for at formelle krav om aktiv jobsøgning og fysiske samtaler blev suspenderet og dagpengeperioden forlænget, tyder undersøgelsen imidlertid på at ejerskabet til og selvansvaret for jobsøgningen steg blandt de coronaledige.

Temanummerets anden artikel 'Hvad coronakrisen fremkalder om ledelse af trivsel på distancen' og er skrevet af Malene Friis Andersen og Claus Elmholdt. Artiklen beskæftiger sig med distanceledelse; det fænomen ledere pludselig skal lede virtuelt fra distancen som følge af nedlukningen og hjemsendelsen af mange medarbejdere. På den baggrund undersøger forfatterne, hvordan distanceledere oplever at medarbejdernes behov for ledelse, og hvilke de praksisser de udvikler for at lede medarbejdernes trivsel på distancen. På baggrund af 47 kvalitative interviews med distanceledere gennemført under coronakrisens første måneder, identificerer forfatterne induktivt 6 ledelsespraksisser, som distancelederne anvender til at understøtte medarbejdernes trivsel på distancen. Disse ledelsespraksisser handler bl.a. om at skabe en bedre balance mellem krav og ressourcer og om at sætte distanceledernes viden om medarbejdernes individuelle privatsfære i spil. Alt i alt peger Andersen og Elmholdt på, at der kan være behov for andre typer af handlinger fra lederen, når trivsel ledes $\mathrm{i}$ en digital og ikke fysisk kontekst.
Dernæst følger en artikel af Lotte Holck og Iben S. Stjerne, med titlen 'HR og Krisehåndtering: læring fra 15 HR chefers håndtering af Covid-19 Krisen', som belyser hvordan krisen forandrer arbejdslivet for HR-chefer, der i deres praksis skal balancere mellem hård og blød human ressource management. Artiklen bygger på kvalitative interviews med 15 danske HR-chefer over flere omgange i perioden marts 2020 til marts 2021. Holck og Stjerne peger på, hvordan den krisehåndtering som udøves under coronapandemien forstærker dilemmaet i HR mellem at være ledelsens 'forlængede arm' og varetage medarbejdernes trivsel. Forfatterne viser, hvordan fokus for HR-cheferne pludselig skifter fra medarbejdertrivsel og -udvikling til 'hård' HRM med fokus på afskedigelser og omplaceringer. De peger således på, hvordan coronakrisen er med til at synliggøre og forstørre den grundlæggende spænding mellem hensyn til økonomi og ledelseseksekvering og så arbejdet med medarbejderudvikling og -trivsel, og således udfordrer HR chefernes arbejde.

Endelig præsenterer Trine P. Larsen og Anna Ilsøe i artiklen 'De Nordiske Covid-19 hjælpepakker og atypisk beskæftigede: erfaringer med universelle og målrettede tiltag' en komparativ undersøgelse af hvordan de nordiske lande responderede på krisen. På trods af at alle fem lande blive betragtet som en del af den samme universelle, nordiske velfærdsmodel, er der alligevel en række forskelle i den måde pandemien blev håndteret på i forhold til hjælpepakker. I såvel Danmark som Sverige har hjælpepakkerne i højere grad været målrettet bestemte grupper på arbejdsmarkedet; især dem med mere almindelige arbejds- og ansættelsesvilkår. Forfatterne peger på, at selvom hjælpepakkerne i mange tilfælde har været relativt generøse, har det betyder at hjælpepakkerne kun i begrænset omfang kom til at omfatte mennesker med atypiske beskæftigelser Som kontrast hertil står nogle af de foranstaltninger som blev 
gennemført i Norge, Finland og Island. Her blev ordningerne designet på en måde som var mere universelle, f.eks. fordi de ikke forudsatte f.eks. a-kassemedlemskab eller på anden måde var målrettet bestemte grupper. Til gengæld var de i mange tilfælde mindre generøse, hvis man ser på graden af kompensation i forhold til den tidligere indtægt. Alt i alt peger Larsen og Ilsøe på at hjælpepakkerne kan være medvirkende til at øge uligheden på arbejdsmarkedet i retning af de tendenser til segmentering der allerede finder sted

Temanummerets kronik har titlen 'Nye arbejdslivsbalancer under corona - muligheder og udfordringer for ledelse og medarbejdere' og er skrevet af Steen E. Navrbjerg og Dana Minbaeva. I kronikken beretter Navrbjerg og Minbaeva først om forskningsprojektet 'Virtuel ledelse under corona', som blev udviklet på ganske få dage i foråret 2020, da nedlukningen var en realitet og som de modtog fondsmidler til ganske kort tid efter. Ud over en interessant insiderfortælling om, hvordan det er at bedrive forskning, mens corona udvikler sig og hele tiden skaber forandringer i det objekt, der studeredes, så beskriver Navrbjerg og Minbaeva også de væsentligste resultater fra forskningsprojektet, hvor de har interviewet arbejdsgiverrepræsentanter og medarbejdere og ledelser på 18 virksomheder samt udsendt spørgeskemaer. De afslutter kronikken med at reflektere over, hvad corona krisen har lært os om ledelse og arbejdsliv og hvilke ændringer, vi kan forvente at se i fremtidens arbejdsliv. Her stiller de bl.a. skarpt på, at vi under coronakrisen så en omfattende sammenblanding af arbejdslivet og familie- og privatlivet, og de stiller afslutningsvist spørgsmålet, om hvorvidt denne sammenblanding for nogle faktisk udgør en hensigtsmæssige arbejdslivsbalance.

God Læselyst

Stine Rasmussen, Thomas Bredgaard, Claus D. Hansen \& Annette Kamp 